\title{
Teaching Style and Mental Representation of Teachers in Biology Learning Using Convention Picture
}

\author{
F Ramadhan ${ }^{1}$, A Rahmat ${ }^{2}$, and E Nuraeni ${ }^{2}$ \\ ${ }^{1}$ Program Studi Pendidikan Biologi, Sekolah Pascasarjana Universitas Pendidikan Indonesia, Jl. \\ Dr. Setiabudi No. 229, Bandung 40154, Indonesia \\ ${ }^{2}$ Departemen Pendidikan Biologi, Universitas Pendidikan Indonesia, Jl. Dr. Setiabudi No. 229, \\ Bandung 40154, Indonesia \\ adirahmat@upi.edu² \& fitraramadhan22@student.upi.edu ${ }^{1}$
}

\begin{abstract}
Activities of teacher's working memory in representing a picture are important in the teaching and learning process. This study aimed to reveal the tendency of teacher's mental representation and teacher's teaching styles in biology class using convention pictures. This research used descriptive method. The research was conducted by involving four high school biology volunteer teachers of grade XI from four schools in Lebak, Banten, Indonesia. Teacher's teaching styles were measured by questionnaires and rubrics adapted from Grasha and teacher's mental representations were measured using worksheets and rubrics developed based on the Causal Network Elicitation Technique (CNET) model. The data obtained were analyzed qualitatively. The results showed two dominant teacher teaching styles; there were expert style and facilitator style. The mental representation of teachers when reading convention picture was in the category of good ( 2 teachers), adequate ( 1 teacher) and inadequate (1 teacher). A teacher with expert teaching style tends to have a good mental representation compared to a teacher with facilitator teaching style.
\end{abstract}

Keyword : teaching style, mental representation, convention picture

\section{Background}

Picture become one of the most important media in the learning process. In communicating the concepts of biology teachers should be able to create the representations through various media to provide a good understanding for students. The ability of the teacher in communicating it is based on the processing of information through cognitive activity based on something seen (visual) and something heard (verbal), this ability is called mental representation.

According to Sternberg [1], mental representation is the process of recording ideas, knowledge, or messages physically. More precisely can be defined as the use of 'signs' (pictures, sounds, etc.) to represent something absorbed, sensed, imagined, or something felt in physical form. A teacher's mental representation that describes concepts gets from experience and result of interaction from something that exists in its environment either verbal or visual. The process of information processing in a person occurs through two systems, namely through verbal systems and nonverbal systems that refer to dual coding theory. According to Paivio [2], information received by a person is 
processed through one of two systems, namely verbal systems such as text and sound, and visual systems (nonverbal images) such as diagrams, drawings, and animations. Both of these systems can function independently, in parallel, or simultaneously together. Both information systems have different characteristics. Verbal systems process information sequentially while nonverbal systems process information simultaneously (synchronously) or parallel.

Beside a good mental representation in communicating a concepts, the teaching style also had an effect to conveying the concepts to the students. Basically, teachers already have their teaching styles that arise from their habits and personality. According to Eble [3] which reveals that the style of teaching is represented by the personal qualities and behaviors that appear in the organization of the class. According to Bannet in Larenas et al. [4] the teaching style refers to the personal behavior of teachers and the media used during interaction with learners. This characteristic can be seen even when teachers use different approaches as well as different methods of learning. Heimlich and Norlan in Larenas et al. [4] revealed that the style of teaching refers to the style as a penchant for teaching behavior and the appropriateness between teaching behavior and beliefs to teach. Also, According to Zhang in Chen [5], teaching style is not just a technique or style, but also includes teacher's thinking ways and teacher's thinking styles in teaching and teacher's thinking ways in determining strategy.

In biology learning, the sense system concept (the process of seeing) is a concept that intersects with everyday life because it involves the body process so that the concept is considered important. However, in reality, despite the intersection of everyday life, students in schools still regard the material of the visual process as difficult to understand because its characteristics consist of abstract physiological concepts, which require students to associate between the structure of organ tissues and their physiological processes [6]. The results of research by Ainsworth [7] and Assaraf [8], show that system learning involves an integrated understanding of different types of representation. Also, learning about the system requires not only understanding but also having to understand the relationships formed and the overall view of the system being taught. Therefore, the teacher as the informant must have a good ability in describing information about the process of vision so that information received by students can be formed properly.

\section{Method}

This research used a descriptive method. This method is used to describe the pattern of teacher's mental representation when faced convention picture and to describe teacher's teaching style in biology learning and to see the tendency between teaching style and the pattern of teacher's mental representation. The participants of this research are biology's teacher who is teaching at State Senior High Schools at XI grade in Lebak. 10 participants were involved in the research, but only four people followed it to completion. Four teachers involved in this research have different educational backgrounds, two teachers are graduated from biology education, one teacher graduated from biology program, and one teacher graduated from the agricultural program. 
Participants were selected based on convenience sampling techniques. Teacher's teaching styles measured by questionnaires and rubrics adapted from Grasha [9], teacher's teaching style was teaching expert style, formal authority teaching style, personal model teaching style, facilitator teaching style and delegator teaching style. Teacher's mental representation measured by worksheets and rubrics developed based on CNET model [10]. The CNET worksheet measured teacher's mental representation in expressing the element of information presented in the picture. Assessment of mental representation through CNET worksheet consists of four stages: (1) Determining information elements presented in the picture, (2) Determining information sequence accuracy, (3) Determining correlation between elements information presented in the picture and (4) Determining tendency's value of causal network correlation that formed from each measurement step. Pattern of representation in this study is seen based on Bayesian network which is often used to represent causal relationship, there are some form which referred to as topological order In representing a causal relationship, namely markov chain, feedback control with a single measurement, repeated feedback control with multiple measurements, coupled lengevin equations, coupled dynamics with a time delay, complex dynamics [11]. The data obtained were analyzed qualitatively.

\section{Result and Discussion}

Based on the results of the research, from the four teachers, there are wo styles that have the highest score there were: Expert teaching style (2 teachers) facilitator teaching style ( 2 teachers). Scores obtained by each teacher can be seen in the following graph:

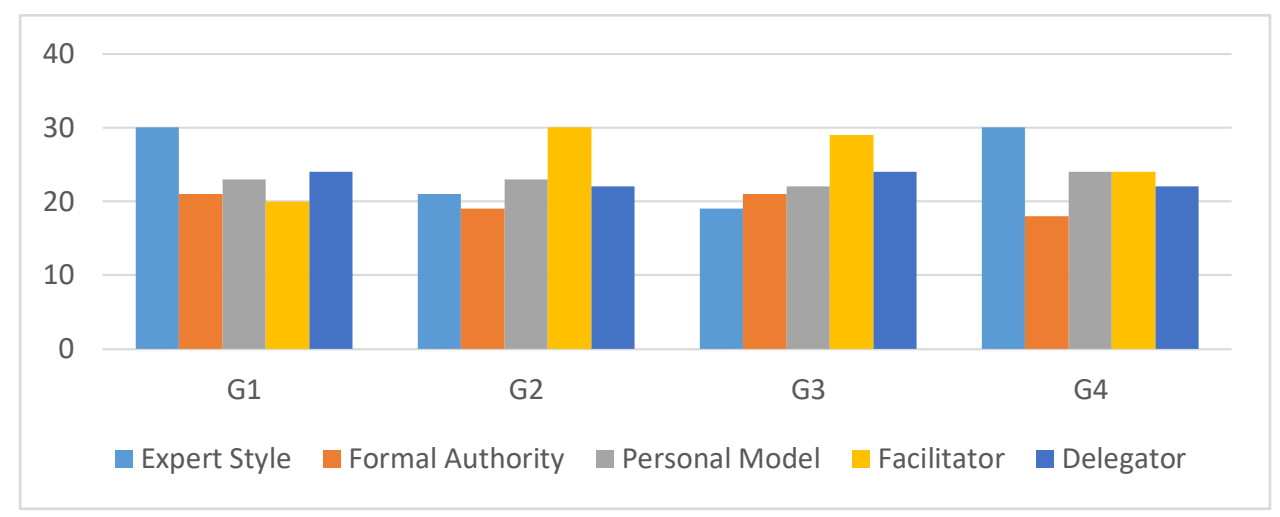

Figure 1. Teacher's Teaching Style Score

Based on Figure 1 it can be seen that the score on the expert teaching style in teachers 1 and 4 is higher than in teachers 2 and 3. Teaching using expert teaching style, teachers feel they have the knowledge and skills required by students and maintain the status as an expert between students by displaying knowledge in detail and by challenging students to improve their competence. Facilitator teaching style use student approach central. Teachers act as facilitators and responsible to students to achieve good results on a variety of tasks. Teachers usually design group activities that require active learning, student collaboration on students and problem-solving. 
Furthermore, the aspect reviewed in this research is Mental Representation. Mental representation according to the CNET model has been developed. There is a difference

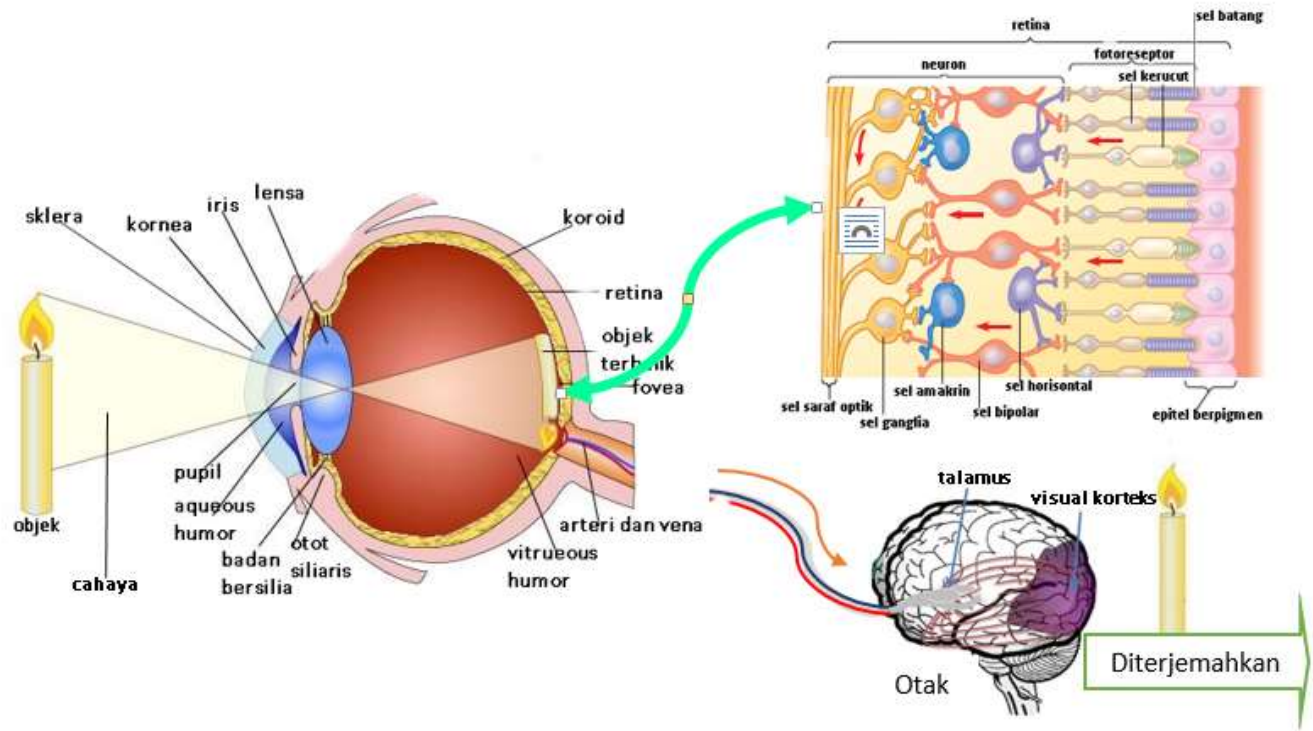

in mental representation scores on each teacher in exposing each information picture element at each step.

Figure 2. Visual Process

Figure 2 is a picture that used to express teacher's mental representation about a visual process, that picture is usually use by teacher in the learning process. The picture above shows information element about the structure of the eyeball and visual process from entering of the light until the object is echoed by the brain. Some of the questions in the worksheet guide respondents to determine and arrange the information elements which have a role in the visual process. Determine the accuracy of the information elements by providing reasons to determine the sequence of the information elements and find the relationship between elements of information in the picture.

\subsection{Determining and Sorting The Elements of Information Presented in The Picture}

In this stage, respondents are asked to select the main information elements in the picture and sort the main information elements and explain the visual process correctly. Based on the answers from 4 respondents, only two respondents can choose and sort16 information in detail so that they can explain the visual process correctly. While two other respondents chose and sorted the main information incomplete so they cannot explain the visual process correctly. 
Table 1. The Main Element Information of Visual Processing and Respondent's Answering

\begin{tabular}{|c|c|c|}
\hline $\begin{array}{c}\text { The Main Element Information } \\
\text { of Visual Processing }\end{array}$ & $\begin{array}{l}\text { Respondent's } \\
\text { Code }\end{array}$ & Respondent's Answering \\
\hline \multirow[t]{3}{*}{$\begin{array}{l}\text { Light - cornea - aqueous humor } \\
\text { - pupil - lens - vitreous humor- } \\
\text { fovea - bacillus cell/cone cell - } \\
\text { horizontal cell - bipolar cell - } \\
\text { amacrine cell - ganglia cell - } \\
\text { optical neuron cell - brain- } \\
\text { visual cortex - object }\end{array}$} & G1 & $\begin{array}{l}\text { Light - cornea - aqueous humor } \\
\text { - pupil - lens - vitreous humor- } \\
\text { fovea - bacillus cell/cone cell - } \\
\text { horizontal cell - bipolar cell - } \\
\text { amacrine cell - ganglia cell - } \\
\text { optical neuron cell - brain- } \\
\text { visual cortex - object }\end{array}$ \\
\hline & G2 & $\begin{array}{l}\text { Cornea-pupil-lens-fovea- cone } \\
\text { cell - bacillus cell-optical } \\
\text { neuron cell }\end{array}$ \\
\hline & G3 & $\begin{array}{l}\text { Cornea - aqueous humor-iris- } \\
\text { pupil - retina - bacillus cell cone } \\
\text { cell-optical neuron cell - brain } \\
\text { Light - cornea - aqueous humor } \\
\text { - pupil - lens - vitreous humor - } \\
\text { fovea - bacillus cell/cone cell - } \\
\text { horizontal cell - bipolar cell - } \\
\text { amacrine cell - ganglia cell - } \\
\text { optical neuron cell - brain - } \\
\text { visual cortex - object }\end{array}$ \\
\hline
\end{tabular}

Table 1 Showed that each respondent has a difference in selecting and sorting the main information elements in the picture. This is possible because each respondent has different accuracy in seeing a picture. The picture above has a lot of information, but only some information elements can show the visual process.

\subsection{Determining Information Sequence Accuracy}

In this stage, the respondent asked to provide the underlying reasons for selecting and sorting the main information elements. Based on four respondents' answers only two respondents can provide the right reason as the basis for sorting the main information elements. While two other respondents cannot provide the right reason as the basis for sorting the main information elements. 
Table 2. The Reason of Sorting Element Information

\begin{tabular}{|c|c|c|}
\hline $\begin{array}{l}\text { Respondent's } \\
\text { Code }\end{array}$ & Order of Element Information & Reasons \\
\hline G1 & $\begin{array}{l}\text { Light - cornea - aqueous humor - pupil } \\
\text { - lens - vitreous humor - fovea - bacillus } \\
\text { cell/cone cell - horizontal cell - bipolar } \\
\text { cell - amacrine cell - ganglia cell - } \\
\text { optical neuron cell - brain- visual } \\
\text { cortex-object }\end{array}$ & $\begin{array}{l}\text { Based on sequences } \\
\text { entering light } \\
\text { processing into eyes } \\
\text { until eyes respond to } \\
\text { object. }\end{array}$ \\
\hline G2 & $\begin{array}{l}\text { Cornea-pupil-lens-fovea- cone cell - } \\
\text { bacillus cell-optical neuron cell }\end{array}$ & Based on causal effect. \\
\hline G3 & $\begin{array}{l}\text { Cornea - aqueous humor-iris-pupil - } \\
\text { retina - bacillus cell cone cell - optical } \\
\text { neuron cell-brain }\end{array}$ & $\begin{array}{l}\text { The light will pass } \\
\text { through above parts. }\end{array}$ \\
\hline G4 & $\begin{array}{l}\text { Light - cornea - aqueous humor - pupil } \\
\text { - lens - vitreous humor - fovea - bacillus } \\
\text { cell/cone cell - horizontal cell - bipolar } \\
\text { cell - amacrine cell - ganglia cell- } \\
\text { optical neuron cell - brain-visual } \\
\text { cortex - object }\end{array}$ & $\begin{array}{l}\text { Starting light has been } \\
\text { received into eyes and } \\
\text { then following become } \\
\text { to be a neuron signals } \\
\text { that they become } \\
\text { neuron signals. They } \\
\text { were sent to brains. }\end{array}$ \\
\hline
\end{tabular}

Table 2 Showed that when respondents select and sort the main elements of the information completely, then the basic reasons in sorting the main information element will be right. However, if the respondent chooses and sorts the main information inaccurately, then the basic reason in sorting the main information will be wrong, because the convention picture represents the structure and process so that if the element of information is less, the process cannot run properly.

\subsection{Determining Correlation Between The Elements of Information Presented in The Picture}

In this stage, respondents are asked to connect between the main information elements that exist in the picture. Based on four respondents' answers, two respondents were able to connect some main information elements, while the other two respondents were unable to connect the main information element yet. 
Table 3. Correlation Between Elements Information and Respondent's Answering

$\begin{array}{ccc}\begin{array}{c}\text { Relationship Between Elements } \\ \text { Information }\end{array} & \begin{array}{c}\text { Respondent's } \\ \text { Code }\end{array} & \begin{array}{c}\text { Respondent's } \\ \text { Answering }\end{array}\end{array}$

1. Cornea receives light and transfer to Aqueous humor then they biased to focus entry the eyes.

The light enter into
cornea then they will be transferred to aqueous humor for biased.

2. The light enters to lens will be transferred to vitreous humor

The lens is elastic

3. The Pupil arrange the light that enters to lens, and then lens will adapt biconvex structure themselves based on the entering light The Pupil has a function to arrange the light.

The Pupil has a function to arrange the light entering the lens. The lens can adapt themselves based on the entering light.

Table 3 Showed some respondents able to connect some elements of information that exist in the picture of vision process. Some others have not been able to connect the main information elements that exist in the picture but able to explain the function of the parts of eyes.

\subsection{Determining Tendency's Value of Causal Network Correlation that Formed from Each Step Measurement}

In this stage, a causal network profile which is the combination of measurement results at each step will describe the result of causal network performance. Based on the results of the research, the representation scores of each teacher was different from each other. The score of each respondent measured based on the stages on CNET. Each score will be categorized based on Arikunto categorization [12].

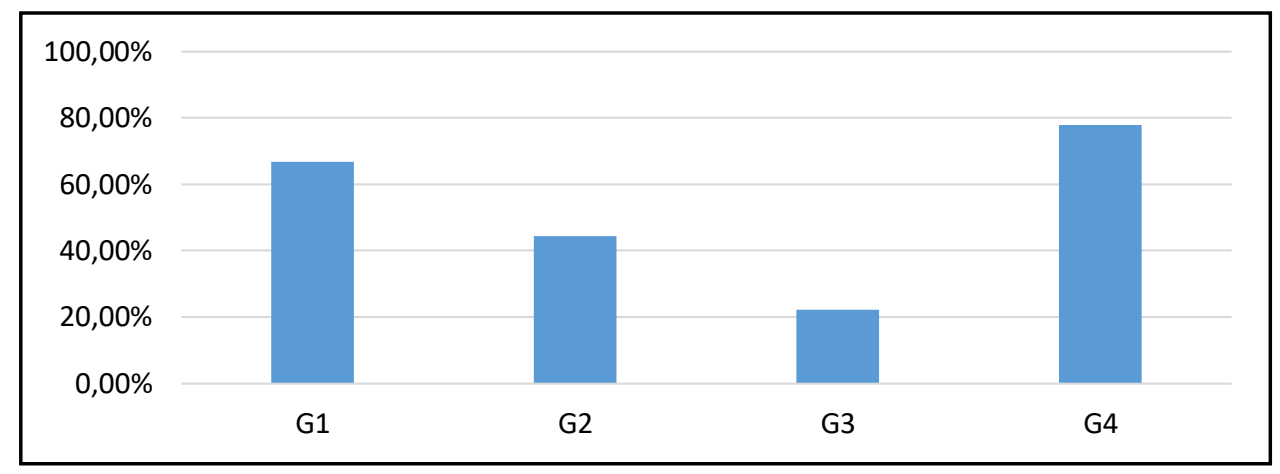

Figure 3. Score of Teacher's Mental Representation while Reading Convention Picture Visual Process 
Table 4. Mental Representation Categories [12]

\begin{tabular}{cc}
\hline Category & Score interval \\
\hline Excellent & $81-100$ \\
Good & $61-80$ \\
Adequate & $41-60$ \\
Inadequate & $21-40$ \\
Very Inadequate & $0-20$ \\
\hline
\end{tabular}

Figure 3 shows the respondents (G1 and G4) have a good mental representation value with representation value of $66.70 \%$ and $77.80 \%$. This indicates that respondents (G1 and G4) can select, sort, give basic and connect the main information elements. While the respondents (G2 and G3) have adequate and inadequate mental representation value with the representation value of $44.40 \%$ and $22.20 \%$. In the adequate category respondent able to selects, sorts and gives a reason, but have not been able to connect the main information elements. In the inadequate category, respondent has not been able to select, sort, gives a reason and connect the main information elements that exist in the picture.

The visible pattern of mental representation of each teacher's answer includes a markov chain pattern that shows that the main information element is equal to other information elements, or has only 1 or 2 relationships between other information elements.

Based on figures 1 and 3 it can be seen that teachers with expert teaching styles have a tendency of good mental representation than facilitator teaching style. It can be seen from the representation value of G1 and G4 of $66.70 \%$ and $77.80 \%$ which include in the good category, and the highest score of teaching style questionnaire is teaching expert style. Otherwise, the representation values of G2 and G3 was $44.40 \%$ and $22.20 \%$ included to adequate and inadequate categories, have a tendency with facilitator teaching style. Based on the recording of teaching learning process in the class teacher with teaching expert style very emphasis on the content. The teacher always explains the concepts clearly and explain the function and its relationship to the content. Because of the teacher always emphasis on the content, then the teacher always preparing himself to release his best ability in mastering content in detail and precisely, this becomes the basis of the higher compatibility between information obtained from the respondents with the causal network formed, it signifies the greater the level of mental representation formed [10].

\section{Conclusion}

The teaching style of each individual was different depending on the way they think in determining learning strategy. In this research, there were two teaching styles with the highest score there were expert teaching style and facilitator teaching style. The mental representation of teachers also different from each other, because the way each individual think was different depends on their experiences, both verbal and nonverbal. There are three categories of teacher's mental representation, good (with value 66.70\% 
and $77.80 \%$ ), adequate (with value $44.40 \%$ ), and inadequate (with value $22.20 \%$ ). Expert teaching style has a tendency of good mental representation than facilitator teaching style.

\section{Acknowledgements}

We would like to say thank you to all teachers who support and involved in our research. Furthermore, we kindly say thank you also to Headmasters who give us an opportunities to have this research in their schools.

\section{References}

[1] Sternberg, R. J.2008. Psikologi Kognitif. Edisi Keempat. Yogyakarta: Pustaka Pelajar

[2] Paivio, A. 1990. Mental Representation: A Dual Coding Approach. (Edisi ke sembilan). New York: Oxford University Press, Inc

[3] Eble, K. E.1980. Teaching Style and Faculty Behavior. In K. E. Eble (ED). Improving Teaching Style. San Fransisco: Josey-Bass

[4] Larenas, C. H., Moran A. V., \& Rivera K. J. 2010. Journal of National Columbia University, Science Human Faculty. Bogota: Colombia, 131.

[5] Chen, G. H. \& Watkins. D. 2010. Psychological Report, 1062.

[6] Lazarowitz. R., Penso S. 1992. High School Student's Difficulties in Learning Biology Concepts. Journal of Biological Education, 263

[7] Ainsworth, S., \& Loizou, A., 2003. Cognitive Science, 274

[8] Assaraf, O. B., Dodick, J., \& Tripto, J. (2013). Research in Science Education, 43 1

[9] Grasha, A. 1996. Teaching with style: a practical guide to enhancing learning by understanding teaching and learning styles. USA: alliance publishers.

[10] Arentze. T., Dellaret, B.G.C., \& Timmersman, H.J.P. 2008. Environment and Behavior, 406.

[11] Ito S 2016 Information Thermodynamics on Causal Networks and its Application to Biochemical Signal Transduction Springer Theses (Singapore: Springer Science + Business Media)

[12] Arikunto, S. 2010. Prosedur penelitian: Suatu Pendekatan Praktik. (Edisi Revisi). Jakarta: Rineka Cipta 